\title{
Unmanned Military Systems and Extraterritorial Application of Human Rights Law
}

Robert Frau ${ }^{1}$

DOI: $10.21827 / 5 a 86 a 7087 b b 5 b$

\author{
Keywords \\ DRONES, HUMAN RightS LAW, EXTRATERRITORIAL APPLICATION OF HUMAN \\ RIGHTS LAW, JURISDICTION
}

\begin{abstract}
The article addresses human rights issues that arise from the use of unmanned military systems in armed conflict. It is assessed when and to what extent human rights law applies in times of armed conflict. The major focus is the question of whether or not human rights law applies extraterritorially. It is argued that it applies to a greater extent to the use of unmanned military systems than might be expected under the jurisprudence of the European Court of Human Rights. Hence, a new approach to the concept of 'jurisdiction' is submitted. In addition, specific scenarios, in which unmanned military systems are frequently deployed, are measured against the legal framework.
\end{abstract}

\section{Introduction}

The world is facing a pandemic of unmanned military systems. Little more than ten years ago, the United States had almost no unmanned aerial vehicles deployed. Today, this number has risen to a five-digit-number. ${ }^{2}$ In addition to aerial vehicles, other unmanned military systems (UMS) are being developed, ranging from naval to ground vehicles, and from weaponised to unweaponised units. ${ }^{3}$ With the use of such UMS, human rights issues arise. In Pakistan alone, for example, more than 2,500

\footnotetext{
Dr. Robert Frau is Senior Research Associate at the Chair of Public Law, especially Public International Law, European Law and foreign Constitutional Law, Faculty of Law, European University Viadrina in Frankfurt (Oder), Germany.

This article is based on a report written for the Swedish National Defence College, Stockholm. The author is grateful to Dr. Heather Harrison Dinniss, Mrs. Jessica Appelgren and Dr. Jann K. Kleffner LL.M. for their valuable comments. The views expressed therein do not express the view of the Swedish National Defence College but remain solely the views of the author. He can be contacted viafrau@europa-uni.de.

2 Singer, P., Wired for War, Penguin, New York 2009, 61.

3 A good overview is provided in US Department of Defense, Unmanned Systems Integrated Roadmap: 2009-2034, 20 April 2009, Washington DC.
} 
persons have been killed by drone strikes. ${ }^{4}$ Human rights issues are especially crucial in times of armed conflict. In public opinion, it is loudly claimed that drone strikes violate human rights law (HRL) or are the devil's handiwork. ${ }^{5}$ But is this true? It is easy to claim that human rights law applies, yet, this is not so easy to establish when drones are remotely controlled from thousands of miles away.

The present article addresses these issues. First, it needs to be established whether or not human rights law applies in times of armed conflict (II). More importantly, it must be assessed where human rights law is applicable; in other words, to what extent it applies extraterritorially (III). It is argued that it applies to a greater extent than might be expected. Hence, a new definition of 'jurisdiction' is submitted. Lastly, the substantive rights at issue during the use of unmanned military systems will be addressed (IV).

The article focuses on unmanned aerial systems (UAVs). Other unmanned military systems may be subject to the same reasoning. ${ }^{6}$ The legal analysis focuses on the United Nations International Covenant on Civil and Political Rights (ICCPR) ${ }^{7}$ and on the Convention for the Protection of Human Rights and Fundamental Freedoms commonly known as the European Convention on Human Rights. ${ }^{8}$

\section{Applicability of Human Rights Law}

\section{II.1. Personal Scope of Applicability}

A State is bound by the human rights instruments it has ratified. Every State organ, whether it belongs to the executive, legislative or judicial branch of government, must - as a minimum - respect human rights. During every use of machinery, whether the device is semi- autonomous or fully-autonomous or not autonomous at all, the State deploying the system remains bound by human rights law as long as the State has jurisdiction over an act ${ }^{9}$ - a pivotal term, as will be shown.

To be very clear: no unmanned system enjoys protection under human rights law whatsoever. Regardless of how human-like such systems may become in the future, they will never be human. This is self-evident, but needs to be highlighted because demands are being raised that such systems should be entitled to combatant status. This would, most likely, contain demands regarding human rights. Under the law, as

4 International Human Rights and Conflict Resolution Clinic, Global Justice Clinic, Living under Drones: Death, Injury, and Trauma to Civilians from US Drone Practices in Pakistan, September 2012, available online at $<\mathrm{http}: / /$ livingunderdrones.org $>$ (accessed 4 October 2012), 29 et seq.

5 Cf. only The Guardian Online, Smith, C. S., Drones: the west's new terror campaign, The CIA's Predator drones are bringing to Pakistan the same horror that Hitler's doodlebugs inflicted on London, The Guardian Online, 25 September 2012, available online at $<$ http://www.guardian.co.uk/commentisfree/2012/sep/25/drones-wests-terror-weaponsdoodlebugs-1> (accessed 7 October 2012).

6 Cf. Frau, R., "Regulatory Approaches to Unmanned Naval Systems in International Law of Peace and War", Journal of International Law of Peace and Armed Conflict 2012, 84-91.

7 International Covenant on Civil and Political Rights of 19 December 1966, 999 UNTS 171, subsequently referred to as ICCPR. The Convention against Torture and Other Cruel, Inhuman or Degrading Treatment or Punishment of 10 December 1984, 1465 UNTS 85, subsequently referred to as CAT, is of lesser importance.

8 The Convention for the Protection of Human Rights and Fundamental Freedoms of 4 November 1950, 213 UNTS 221, subsequently referred to as ECHR.

9 Cf. Art. 1 ECHR, art. 2 ICCPR. 
it is, there is no possibility to confer any rights on machines. Thus, only human beings are entitled to protection under human rights law. ${ }^{10}$

\section{II.2. The Nature of Human Rights Obligations and the Temporal Scope of Applicability}

Under human rights law, a State has the primary duty to refrain from violating the rights under the respective treaties (the "negative" obligation). ${ }^{11}$ The secondary, "positive", obligation is the obligation to fulfil the obligations under the respective treaties. ${ }^{12}$ Hence, a State must not permit or fail to take appropriate measures or to exercise due diligence to prevent, punish, investigate or redress the harm to human rights caused by such acts by private persons or entities. ${ }^{13} \mathrm{~A}$ human right may be violated by a direct act of a State organ or by a failure to protect an individual from a violation by any other than an act of a State organ. Regarding the jurisdiction ratione temporis, human rights law applies at all times as long as a State has jurisdiction.

In times of armed conflict, the law of armed conflict applies. The conflict's character as international or non-international is of no importance. ${ }^{14}$ The law of war or, in other words, international humanitarian law (IHL) also applies in other situations that are not prima facie viewed as an 'armed conflict' but are, nevertheless, considered an 'armed conflict' by law, and thus international humanitarian law applies. Such situations include belligerent occupations and joint military operations. ${ }^{15}$

Not until a few years ago the overwhelming majority of courts and legal scholars were of the opinion that human rights law and the law of armed conflict were mutually exclusive. ${ }^{16}$ This explains why the extent to which human rights law applies in times of armed conflict remains uncertain, even though human rights law and international humanitarian law are not considered mutually exclusive anymore. ${ }^{17}$

10 Organizations with legal personality may also be entitled to protection, but this is of no relevance for the present purpose.

11 Human Rights Committee, The Nature of the General Legal Obligation Imposed on States Parties to the Covenant, General Comment 31, UN Doc. CCPR/C/21/Rev.1/Add.13 of 26 May 2004, para. 6.

12 Ibid., para. 7.

13 Ibid., para. 8.

14 Cf. common art. 2 GC I-IV, art. 1 AP I, art. 1 AP 2.

15 De Schutter, O., International Human Rights Law, Cambridge University Press, Cambridge, 2010, 125; Dinstein, Y., The International Law of Belligerent Occupation, Cambridge University Press, Cambridge, 2009, 161-201.

16 For the historical evolution of the relationship, cf. Kolb, R., "Human Rights and Humanitarian Law", in: Wolfrum, R., ed., The Max Planck Encyclopedia of Public International Law, Oxford University Press, online edition, available online at <http:///www.mpepil.com> (accessed 14 February 2013), paras. 3 et seq.; Droege, C., "The Interplay between International Humanitarian Law and International Human Rights Law in Situations of Armed Conflict"; in: Israel Law Review 40 (2007), 310 et seq.

17 Cf. Kolb, R., supra note 16; Droege, C., supra note 16; Sivakumaran, S., "International Humanitarian Law", in: Moeckli, D., Shah, S., Sivakumaran, S., eds., International Human Rights Law, Oxford University Press, Oxford, 2010, 530 et seq.; Dinstein, Y., The Conduct of Hostilities under the Law of International Armed Conflict, Cambridge University Press, Second Edition, Cambridge University Press, Cambridge, 2010, paras. 44 et seq.; Dinstein, Y., The International Law of Belligerent Occupation, supra note 15, paras. 195 et seq.; Kleffner, J., "Human Rights and International Humanitarian Law: General Issues", in: Gill, T. and Fleck, D., eds., The Handbook of the International Law of Military Operations, Oxford University Press, Oxford, 2010, para. 4.02; Gillard, E.-C., "International Humanitarian Law and Extraterritorial State Conduct", in: Coomans, F., and Kamminga, M. eds., Extraterritorial Application of Human Rights Treaties, Intersentia, Antwerp, 2004, 36 et seq.; Orakhelashvili, A., "The Interaction between Human Rights and Humanitarian Law: 
Jurisprudence is divided on the legal framework regulating the relationship. Some authors argue for a merging of the regimes, ${ }^{18}$ while others describe the relationship with the traditional concepts of lex specialis (humanitarian law) and lex generalis (human rights law) ${ }^{19}$ or with the related concept of renvoi, meaning IHL making references to HRL, and vice versa. ${ }^{20}$ However, for the present purpose this dispute is of little importance, for the practical effects remain the same, regardless of the line of arguments. Therefore, the lawyer is responsible for working out:

"with precision areas and questions where the coordinated application of provisions of both branches of the law leads to satisfactory - if not innovative - solutions, securing progress of the law or filling its gaps. [...] The point is not one of derogation by priority [...] but rather one of complex case-by-case mutual reinforcement and complement always on concrete issues. Thus, rather than stressing mutual exclusiveness, be it specialty or priority, it would be better to focus on two aspects: a) gap filling and development of the law by coordinated application of norms of HRL in order to strengthen IHL and vice versa; b) interpretation allowing an understanding of one branch in the light of the other normative corpus in all situations where this is necessary, i.e. in armed conflict or occupation." 21

This is also the view of the International Court of Justice (ICJ). ${ }^{22}$ It subscribed itself to such a reasoning when it was faced with problems regarding the right of life (art. 4 [1] ICCPR) in armed conflict. The Court held that even if the other criteria required by Art. 4 (1) ICCPR are met, art. 4 (2) ICCPR expressively prohibits a derogation of the right to life.

In war, lives are violently ended. This is more than a matter of fact; it is a matter of law: IHL runs counter to the human right concerning extra-judicial deprivation of life. ${ }^{23}$ How can both regulations be brought in conformity? This is the point where the nature of IHL as lex specialis comes into play. Consequently, the ICJ stated in the Advisory Opinion on Legality of the Threat or Use of Nuclear Weapons:

"In principle, the right not arbitrarily to be deprived of one's life applies also in hostilities. The test of what is an arbitrary deprivation of life, however, then falls to be determined by the applicable lex specialis, namely, the law applicable in armed conflict which is designed to regulate the conduct of hostilities. Thus whether a particular loss of life, through the use of a certain weapon in warfare, is to be considered an arbitrary deprivation of life contrary to Article 6 of the Covenant, can

Fragmentation, Conflict, Parallelism, or Convergence?", European Journal of International Law 19 (2008), 161 et seq.

18 Further reference provided by Kolb, R., supra note 16, para. 30; and by Sivakumaran, S., supra note 17,530 et seq.

19 Cf. Dinstein, Y., The Conduct of Hostilities under the Law of International Armed Conflict, supra note 17, paras. 44 et seq.; Dinstein, Y., The International Law of Belligerent Occupation supra note 15, paras. 195 et seq.; Kleffner, J., supra note 17, para. 4.02; Gillard, E.-C., supra note 17, 25 et seq., 36 et seq.

20 Kolb, R., supra note 16, paras. 35 et seq.

21 Kolb, R., supra note 16, para. 44. Dinstein, Y., The Conduct of Hostilities under the Law of International Armed Conflict, supra note 17, para. 60, seems to subscribe to this view.

22 ICJ, Legality of the Threat or Use of Nuclear Weapons, Advisory Opinion of 8 July 1996, ICJ Rep. 1996.

23 Dinstein, Y., The Conduct of Hostilities under the Law of International Armed Conflict, supra note 17, para. 56. 
only be decided by reference to the law applicable in armed conflict and not deduced from the terms of the Covenant itself." 24

Thus, the present article tries to argue in that line of reasoning.

\title{
II.3. Derogations from Human Rights Law in Armed Conflict and other Public Emergencies
}

Derogating from human rights law is lawful only in exceptional circumstances; such as if a state of public emergency exists. Most prominently, art. 4 ICCPR provides that in:

\begin{abstract}
"time of public emergency which threatens the life of the nation and the existence of which is officially proclaimed, the States Parties to the present Covenant may take measures derogating from their obligations under the present Covenant to the extent strictly required by the exigencies of the situation, provided that such measures are not inconsistent with their other obligations under international law and do not involve discrimination solely on the ground of race, colour, sex, language, religion or social origin." 25
\end{abstract}

Case law has identified six prerequisites that need to be fulfilled cumulative before a State may lawfully derogate from its human rights obligations: ${ }^{26} \mathrm{~A}$ state of public emergency that threatens the life of the nation; ${ }^{27}$ the measures derogating from the human rights in question are limited to the extent strictly required by the exigencies of the situation; ${ }^{28}$ these measures are non-discriminatory and are applied in a nondiscriminatory fashion; the State observes its other obligations under international public law; ${ }^{29}$ and certain procedural safeguards were observed. ${ }^{30}$ Additionally, some human rights are non-derogable even in a state of emergency. ${ }^{31}$ Hence, an armed

24 ICJ, supra note 22, para. 25.

25 Cf. Human Rights Committee, States of Emergency, General Comment 29, UN Doc. CCPR/C/21/Rev.1/Add. 11 of 24 July 2001, para. 2 et seq.; De Schutter, O., supra note 15, 513 et seq. Similar provisions are art. 15 (1) ECHR and art. 27 ACHR.

26 Human Rights Committee, Ibid., paras. 2 et seq. Cf. also De Schutter, O., supra note 15, 514

27 This will only be the case in exceptional circumstances. Cf. Human Rights Committee, Ibid., para. 3. Under the ECtHR, not every 'war' amounts to such an exception. Cf. ECtHR, Lawless v Ireland (no. 3), Appl. no. 332/57, 1 July 1961, para. 38, Series A no. 3; ECtHR, Bankovic and others v Belgium and 16 Other Contracting States, Appl. no. 52207/99, 12 December 2001, para. 62. What kind of a factual situation amounts to a public emergency in the meaning of art. $15 \mathrm{ECHR}$ is, first and foremost, an assessment to be made by each government 'as the guardian of their own people's safety', but subject to judicial review by the HRC or the ECtHR. Cf. ECtHR, A. and others v United Kingdom, Appl. no. 3455/05, 19 February 2009, para. 180 et seq.

28 The limitation to the exigencies of the situation is basically a limitation according to the principle of proportionality and concerns the overall application of human rights, not the single instance in which a right was violated and this violation may be justified for reasons of proportionality.

29 Meaning the respective other instruments of human rights law.

30 In essence this means that the emergency has to be officially proclaimed and notified to the other parties to the respective instrument.

31 The ICCPR allows no arbitrary derogation from the right to life (art. 6 ICCPR), no derogation from the prohibition of torture (art. 7 ICCPR) and the prohibition of slavery and servitude (art. 8 [1], [2] ICCPR), imprisonment for failure to fulfil a contractual obligation (art. 11 ICCPR), liberty (art. 12 ICCPR), nulla poena sine lege (art. 15 ICCPR), recognition as a person before the law (art. 16 ICCPR) and freedom of thought, conscience and religion (art. 18 ICCPR). The ECHR does not allow to derogate from the prohibition of torture (art. 3 ECHR), the prohibition of slavery and servitude (art. 
conflict does not automatically allow derogation. Regardless of whether they are performed in an international or a non-international armed conflict, measures derogating from the Covenant are allowed only if and to the extent that the armed conflict constitutes a threat to the life of the nation. ${ }^{32}$

\section{Territorial Scope of Applicability}

Having established that human rights law applies in times of armed conflict, it is crucial to assess if human rights law applies extraterritorially. If this is not the case, claims that drone attacks regularly violate human rights are unfounded.

State parties to the human rights instruments must provide protection to anyone 'within' (art. 1 ECHR) or 'subject to' (Art. 2 [1] ICCPR; art. 1[1] American Convention on Human Rights ${ }^{33}$; art. 3 [1] Arab Charter on Human Rights ${ }^{34}$ ) their jurisdiction. ${ }^{35}$ This concept, based on the sovereign equality of States, ${ }^{36}$ is primarily territorial. ${ }^{37}$ Everyone on the territory of a State party is entitled to protection according to the respective treaties. However, this territorial approach does not mean that human rights law is only applicable to the national territory of a State party. In the words of the ECtHR:

"The concept of 'jurisdiction' under article 1 of the Convention is not restricted to the national territory of the Contracting States. Accordingly, the responsibility of Contracting States can be involved by acts and omissions of their authorities which produce effects outside their own territory." 38

Thus, the term 'jurisdiction' is neither equivalent to, nor interchangeable with, 'attributability' ${ }^{39}$ or 'territory'. However, because human rights obligations are primarily territorial, other bases of jurisdiction are exceptional and require a special justification in the particular circumstances of each case ${ }^{40}$ Case law has identified two exceptions; one definition is guided by a spatial approach and the other by a personal approach to 'jurisdiction', each demanding 'effective control' over territory or, respectively, a person.

4 [1] ECHR) and no punishment without law (art. 7 ECHR). The right to life (art. 2 ECHR) may only be violated by lawful acts of war.

32 Human Rights Committee, General Comment 29, supra note 25 , para. 3.

33 American Convention on Human Rights (Pact of San José) of 22 November 1969, 1144 UNTS 123, subsequently referred to as ACHR.

${ }^{34}$ Arab Charter on Human Rights of 22 May 2004, 12 International Human Rights Report 893 (2005).

35 Cf. ECtHR, Loizidou v Turkey (preliminary objections), Appl. no. 15318/89, 23 March 1995, para. 62; Human Rights Committee, General Comment 31, supra note 11, para. 10; De Schutter, O., supra note 15, 125; Nowak, M., UN Covenant on Civil and Political Rights - CCPR Commentary, N. P. Engel Publisher, Kehl am Rhein, 2005, art. 2, para. 29; Wenzel, N., "Human Rights, Treaties, Extraterritorial Application and Effects", in Wolfrum, R., ed., supra note 16, para. 4; Kleffner, J., supra note 17, para. 4.01.; Milanovic, M., "Al-Skeini and Al-Jedda in Strasbourg", European Journal of International Law 32 (2012), 121 et seq. (122). This point is missing in International Human Rights and Conflict Resolution Clinic, Global Justice Clinic, supra note 4, 117 et seq.

36 ECtHR, Banković, supra note 27, para. 59.

37 De Schutter, O., supra note 15, 124. art. 2 (1) ICCPR, art. 1 ECHR; art. 1 (1) ACHR; art. 26, 34 (5) Arab Charter on Human Rights. ICJ, Legal Consequences of the Construction of a Wall in the Occupied Palestinian Territory, Advisory Opinion of 9 July 2004, ICJ Rep. 2004, 136 et seq., para. 112.

38 ECtHR, Loizidou v Turkey, Appl. no. 15318/89, 18 December 1996, para. 52. Cf. also ECtHR, Drozd and Janousek v France and Spain, Appl. no. 12747/87, 26 June 1992, para. 91; ECtHR, Loizidou (preliminary objections), supra note 35, para. 62.

39 De Schutter, O., supra note 15, 123; Milanovic, M., "From Compromise to Principle: Clarifying the Concept of State Jurisdiction in Human Rights Treaties", Human Rights Law Review 8 (2008), 436 et seq.

40 ECtHR, Banković, supra note 27, para. 61. 


\section{III.1. Spatial Approach: Criterion of Effective Control over Territory}

The spatial approach requires effective control over territory. ${ }^{41}$ It does not require detailed control over the policies and actions of the authorities in question. "Rather, 'effective overall control' is sufficient." ${ }^{43}$ The ECtHR has held a State responsible:

"when the respondent State, through the effective control of the relevant territory and its inhabitants abroad as a consequence of military occupation or through the consent, invitation or acquiescence of the Government of that territory, exercises all or some of the public powers normally to be exercised by that Government." ${ }^{4}$

The question of whether or not a State exercises effective overall control is a matter of fact, not a matter of law. ${ }^{45}$ Effective control can be a consequence of military action - whether lawful or unlawful, or as part of a peace operation outside of a State's national territory. Under the universal human rights instruments, (belligerent) occupation entails effective control, ${ }^{46}$ while the ECtHR decided this question on very formal criteria. ${ }^{47}$ However, bearing in mind the definition, ${ }^{48}$ it becomes evident that a belligerent occupation will in most cases amount to an exercise of effective control. ${ }^{49}$

\section{III.2. Personal Approach: Criterion of Effective Control over an Individual}

The ECtHR ${ }^{50}$, the now defunct European Commission of Human Rights ${ }^{51}$ and the United Nations Human Rights Committee ${ }^{52}$ have also invoked a second approach. The personal approach determines that a State has jurisdiction whenever it exercises

41 It used to be important whether or not the territory over which effective control is exercised belongs to the 'legal space' of the convention, cf. ECtHR, Bankovic, supra note 27, para. 80. Recently, the ECtHR denounced this concept (al-Skeini and others $v$ The United Kingdom, Appl. no. 55721/07, 7 July 2011, para. 142).

42 ECtHR, Loizidou, supra note 38, para. 56.

43 Kleffner, J., supra note 17, para. 4.01.40, with reference to ECtHR, Loizidou, supra note 38, para. 56; Lawson, R., "Life after Bankovic: On the Extraterritorial Application of the European Convention on Human Rights", in Coomans and Kamminga, M., eds., supra note 17, 83 et seq. and 98.

44 ECtHR, Banković, supra note 27, para. 71.

45 Milanovic, M., "From Compromise to Principle: Clarifying the Concept of State Jurisdiction in Human Rights Treaties", supra note 39, 423.

46 Human Rights Committee, Concluding Observations on Israel, UN Doc. CCPR/CO/78/ISR (2003), 21 August 2003, para. 11; Human Rights Committee, Concluding Observations on Israel, UN Doc. CCPR/C/79/Add.93, 18 August 1998, para. 10; Kleffner, J., supra note 17, para. 4.01.39.

47 Milanovic, M., "Al-Skeini and Al-Jedda in Strasbourg", supra note 35,130.

48 Benvenisti, E., "Occupation, Belligerent", in Wolfrum, R., ed., supra note 16, para. 1.

49 Cf. also ECtHR, Loizidou (preliminary objections), supra note 35, paras. 62 et seq.; ECtHR, Ilaşcu and others v Moldova and Russia, Appl. no. 48787/99, 8 July 2044, paras. 382 et seq.

50 ECtHR, Issa and others v Turkey, Appl. no. 16 November 2004, para. 71; ECtHR, Öcalan v Turkey, Appl. no. 46221/99, 12 May 2005, para. 91.

51 European Commission of Human Rights, Cyprus v Turkey, Decision of 26 May 1975, Appl. nos. 6780/74, 6950/75, paras. 8 et seq.

52 Human Rights Committee, General Comment 31, supra note 11, para. 10; Human Rights Committee, Lopez Burgos v Urugay, Communication no. R.12/52, 29 July 1981, UN Doc. Supp. No. $40(\mathrm{~A} / 36 / 40)$ 1981, 176 et seq. 
"authority or control over an individual". ${ }^{53}$ Its relevance was basically limited to persons in the physical custody of a contracting State.

\section{III.3. Tailoring of Human Rights}

The traditional concept of 'jurisdiction' favoured an all-or-nothing-approach, meaning either the human rights instrument was applicable in its entirety, or not at all. A division or tailoring of human rights with regard to the situation of an individual (meaning some human rights may apply while others do not, depending on the extent of effective control), was rejected by the ECtHR. ${ }^{54}$

Recently the Court revised this approach and simply stated that:

"it is clear that, whenever the State through its agents exercises control and authority over an individual, and thus jurisdiction, the State is under an obligation under Article 1 to secure to that individual the rights and freedoms under Section 1 of the Convention that are relevant to the situation of that individual. In this sense, therefore, the Convention rights can be 'divided and tailored'." 55

Although the Court left open how it envisaged such a tailoring, and any prediction remains uncertain, future international jurisprudence will likely opt for the new approach, ${ }^{56}$ especially because the jurisprudence of the ECtHR has been an example for other human rights bodies and its reasoning has been followed throughout the world. ${ }^{57}$

\section{III.4. The Banković and al-Skeini-Approaches in Relation to New Weapons Technology}

Hence, it is submitted that, under the ECHR, the extraterritorial use of unmanned aerial vehicles (UAVs) amounts to 'jurisdiction' in a variety of cases. It will be shown that this is in line with the jurisprudence of the ECtHR.

In its famous Bankovic judgment, the ECtHR declined to find that an aerial bombardment could constitute effective control. ${ }^{58}$ It based this finding, implicitly, on the fact that there were no troops on the ground. ${ }^{59}$ For the State parties it was thus not possible to effectively exercise control at any other point in time but the actual aerial bombardment. In the light of new jurisprudence it has been suggested that "drone

Milanovic, M., "Al-Skeini and Al-Jedda in Strasbourg", supra note 35, 128.

ECtHR, Bankovic, supra note 27, para. 75.

55 ECtHR, al-Skeini, supra note 41, para. 137.

56 Milanovic, M., "Al-Skeini and Al-Jedda in Strasbourg", supra note 35, 131 et seq.; Thienel, T., It's a good day for human rights law 1 and 2, Invisible College Blog, 7 July 2011, available at $<$ http://invisiblecollege.weblog.leidenuniv.nl> (accessed 7 October 2012); R. Lawson, supra note 43, 120 et seq.

57 Harris, D. J., O'Boyle, M. Bates, E.P., Buckles, C. M., eds., Law of the European Convention on Human Rights, Oxford University Press, Oxford, 2009, 30.

58 ECtHR, Bankovic', supra note 27, para. 71 et seq. Cf. also Kleffner, J., supra note17, para. 4.01 .40 et seq.; Milanovic, M., "Al-Skeini and Al-Jedda in Strasbourg", supra note 35, 127 et seq. Note that the Inter-American Court and Commission on Human Rights as taken a different standpoint on this issue, cf. IACtHR, Armando Alejandre Jr. et al. v Cuba, Report No. 86/99, Case no. 11.589, 29 September 1999, paras. 23 et seq.

59 ECtHR, Bankovic, supra note 27, para. 70. Cf. also ECtHR, Loizidou, supra note 38, para. 56; ECtHR, al-Skeini, supra note 41, para. 139. 
operations in Yemen or wherever would be just as excluded from the purview of human rights treaties as under Bankovic."60

The use of UAVs, however, is different from the use of fighter planes. Thus, it is submitted that the ECtHR and other human rights bodies will-and should - in the future consider aerial bombardment by UAVs as the exercise of effective control. The reasons are as follows.

First, UAVs have the technical ability to cruise over an area much longer than planes and at a considerably slower speed. While a plane only flies over the area and spends just a moment above the individual, drones may cruise over individuals for days. ${ }^{61}$ Within that time frame, the deploying armed forces may at any moment decide to launch an attack against that individual. Like the sword of Damocles, the drone reminds the individual that he could be killed in an instant, depending only on the will of the operator miles in another part of the world or the autonomous decision of the drone. The use of drones may therefore be regarded as 'jurisdiction in waiting'. ${ }^{62}$ That the deployment of drones is somehow 'weak', in the sense that nobody is at the scene, does not contradict this finding. After all, even tenuous control is sufficient, as long as it is effective. ${ }^{63}$ In addition, the deploying State is in power to launch an attack on an individual at any moment it pleases. There may not be ground troops, but there are 'troops in the air', able to strike at any time.

Second, taking a life can be considered to be the 'ultimate public power'. The ECtHR took this concept of 'public powers', once reserved for the spatial model of jurisdiction, and declared that it recognised the "exercise of extra-territorial jurisdiction by a Contracting State when, through the consent, invitation or acquiescence of the Government of that territory, it exercises all or some of the public powers normally to be exercised by that Government." 64 Thus, as has been critically noticed, "the ability to kill is 'authority and control' over the individual if the State has public powers, killing is not authority and control if the State is merely firing away missiles from an aircraft." 65

These different assessments of aerial bombardment are, third, arbitrary ${ }^{66}$ From the individual's standpoint, this differentiation does not make sense. However, the interpretation of the jurisdiction-requirement in light of the object and purpose of human rights instruments ${ }^{67}$ demands an extensive reading. Ultimately, the inherent dignity of the human person and the equal and inalienable rights of all members of the human family "is the foundation of freedom, justice and peace in the world." ${ }^{68}$ Thus, in order to establish whether or not human rights law applies, one has to focus on the beneficiary of human rights law, not on the one owing the obligation. Human rights primarily protect the individual against the State as the most powerful entity.

60 Milanovic, M., "Al-Skeini and Al-Jedda in Strasbourg”, supra note 35, 130.

61 This is not to say that 'duration' constitutes an integral part of jurisdiction. The ECtHR may regard this fact of adding to the effectiveness of control, for 'public powers' are not exercised in the blink of an eye, but for hours.

62 'Jurisdiction' does not entail a constant violation of human rights, the term only entails the possibility of such a violation at any given moment. Cf. also Milanovic, M., Extraterritorial Application of Human Rights Treaties: Law, Principles, and Policy, Oxford University Press, Oxford, 2011, 170.

63 ECtHR, al-Skeini, supra note 41, para. 149. Cf. also Milanovic, M., Ibid., 170-173.

64 ECtHR, al-Skeini, supra note 41, para. 135.

65 Milanovic, M., "Al-Skeini and Al-Jedda in Strasbourg”, supra note 35, 130.

66 Lawson, R., supra note 43, 123; Milanovic, M., "Al-Skeini and Al-Jedda in Strasbourg", supra note $35,131$.

67 Art. 31 (1) Vienna Convention on the Law of Treaties of 23 May 1969, 1155 UNTS 331.

68 Preambular paragraphs 1 and 2 ICCPR. 
Consequently, as soon as a State is in the position to violate human rights, this State is bound by human rights law. ${ }^{69}$

Fourth, under the new jurisprudence of the ECtHR ${ }^{70}$ the rights enshrined in the ECHR may be tailored to fit a situation of mere aerial bombardment. ${ }^{71}$ After all, a State may exercise just "some of the public powers"; ${ }^{72}$ consequently, this exercise will be regulated by some human rights, namely those that fit the specific exercise, and those rights in the positive or negative dimension. ${ }^{73}$

One can find support for this view in the ECtHR's jurisprudence. ${ }^{74}$ The Court has held that Iranian nationals, who were crossing the Turkish-Iranian border illegally and were killed by Turkish helicopters, were under Turkish jurisdiction, regardless of the exact whereabouts of the victims on Turkish or Iranian soil. ${ }^{75}$ Thus, an aerial bombing using drones may be regarded a violation of the right to life (art. 2 ECHR) because the State has jurisdiction based on the spatial and/or personal approach; albeit this jurisdiction is limited, it is not less effective. ${ }^{76}$

Truth be told, this view will not stand uncontested. ${ }^{77}$ The human rights instruments do not require 'jurisdiction' without reason. Ultimately, any act of a State outside of its territory capable of violating an individual's human rights would amount to an exercise of 'authority or control' over that individual. ${ }^{78}$ Therefore, 'jurisdiction' must limit a State's obligations in some way. Otherwise, the words 'within their jurisdiction' would be superfluous and devoid of any purpose. ${ }^{79}$

It is, therefore, submitted that the use of UAVs and similar UMS amounts to 'effective control' and 'jurisdiction' if a State exercises 'jurisdiction in waiting', meaning an extraterritorial situation in which a State may exercise all or some of the public powers normally to be exercised by that Government within an instant; this

69 A more detailed analysis with further references will be provided in Frau, R., "Entwicklungen bei der gewohnheitsrechtlichen Einbindung nichtstaatlicher Gewaltakteure", in: Krieger, H., ,Weingärtner, D., eds.: Streitkraefte und nicht-staatliche Akteure, Baden-Baden, forthcoming 2013; Frau, R., Überlegungen zur Bindung nichtstaatlicher Gewaltakteure an internationale Menschenrechte, Humanitäres Völkerrecht-Informationsschriften, 2013, 13 et seq.. Cf. also Clapham, A., Human Rights Obligations of Non-State Actors, Oxford University Press, Oxford, 2006; Clapham, A., "Human rights obligations of non-State actors in conflict situations", International Review of the Red Cross 88 (2006), 491 et seq.; Heintze, H.-J., "Are De Facto Regimes Bound by Human Rights?", OSCE Yearbook 2009, 267 et seq.; Tomuschat, C., "The Applicability of Human Rights Law to Insurgents Movements", in: Fischer, H., Froissart, U.,Heintschel von Heinegg, W., . Raap, C., eds., Krisensicherung und humanitaerer Schutz - Crisis Management and Humanitarian Protection, Festschrift fuer D. Fleck, Berliner Wissenschaftsverlag, Berlin, 2004, 573 et seq.

70 ECtHR, al-Skeini, supra note 41; ECtHR, al-Jedda $v$ The United Kingdom, Appl. no. 27021/08, 7 July 2011.

71 Cf. III.3.

72 Cf. supra note 44 and accompanying text.

73 Milanovic, M., Extraterritorial Application of Human Rights Treaties, supra note 62, 209-222. Cf. also supra II.2.

74 Cf. O'Boyle, M., "The European Convention on Human Rights and Extraterritorial Jurisdiction: A Comment on 'Life after Bankovic'", in Coomans, F., Kamminga, M., eds., supra note 17, 125 et seq. and 138 .

75 ECtHR, Pad and others v Turkey, Appl. no. 60167/00, 28 June 2007, paras. 53 et seq. Cf. Milanovic, M., "Al-Skeini and Al-Jedda in Strasbourg", supra note 35, 124, with further references and case law.

76 Cf. Scheinin, M., "Extraterritorial Effect of the International Covenant on Civil and Political Rights", in Coomans and Kamminga, M., eds., supra note 17, 77 et seq. See also Human Rights Committee, Concluding Observations on Israel 2003, supra note 46, para. 11.

77 Milanovic, M., "Al-Skeini and Al-Jedda in Strasbourg", supra note 35, 139: 'extraterritorial application of the ECHR still rests on shaky ground'.

78 Milanovic, M., Extraterritorial Application of Human Rights Treaties, supra note 62, 187-209.

79 ECtHR, Banković, supra note 27, para. 75. 
exercise regularly entailing the violation of a human right; while the exercise of public powers depending only on the will of the State and not on any other factor or behaviour, especially not on the individual concerned; and the 'jurisdiction in waiting' being exercised over a not negligible length of time that distinguishes the situation from a mere momentarily presence of 'public power' or 'effective control'.

\section{III.5. Summary: the Applicability of Human Rights Law}

In armed conflict, human rights law applies. This is the case, even if the conflict takes place outside of the respective State's territory, albeit with limitations: a State has to fulfil its obligations under human rights law to the extent that it exercises effective control either of territory or over persons. To the extent that effective control may vary, so does the extent of obligations under human rights law.

\section{Possible Scenarios and the Substantive Human Rights at Issue}

It is submitted that a tailored approach to human rights law in armed conflict is possible. Drones and other unmanned military systems are deployed in various circumstances. In the following second part of this analysis the submitted approach will be illustrated with several scenarios, highlighting the most common and likely use of UMS. As will be seen, human rights law must be taken into account in these scenarios.

\section{IV.1. Targeted Killing in Armed Conflicts}

Scenario: An unmanned weapons system singles out an individual as a target. Subsequently, it takes the decision to attack and kills the targeted individual. In this scenario, the right to life may be violated.

The individual was protected under human rights law against an intentional or arbitrary deprivation of his life (art. 2 [1], 15 [2] ECHR and art. 6 [1] ICCPR). However, this right is not applicable in its entirety in armed conflict. During hostilities, international humanitarian law applies. Additionally, the right to life is not guaranteed against lawful acts of war. Therefore, any deprivation of life in armed conflict that constitutes a lawful act of war, cannot be considered a violation of the right to life.$^{80}$ In other words, if during an international armed conflict a combatant is targeted and killed by an unmanned weapons system, this does not violate his right to life. Similarly, if a person who exercises a 'continuous combat function' ${ }^{81}$ during a non-international armed-conflict is targeted and killed by an unmanned weapons system, this also does not violate his right to life. Thus, the lawfulness of the killing depends on the status of the targeted individual. The use of unmanned weapons systems does not pose any new legal challenges. ${ }^{82}$

80 ICJ, Ibid.; art. 15 (2) ECHR.

81 Cf. International Committee of the Red Cross, Interpretive Guidance on the Notion of Direct Participation in Hostilities under International Humanitarian Law, Geneva 2009, rule II.

82 Cf. also Report of the Special Rapporteur on extrajudicial, summary or arbitrary execution, 28 May 2010, UN Doc. A/HRC714/24/Add.6. 


\section{IV.2. Investigation of Targeted Killings}

Scenario: The individual killed in scenario IV.1 was either an enemy combatant or a civilian. The authorities of the State deploying the unmanned weapons system do not investigate the death of the person. In this scenario, the procedural aspect of the right to life may be violated.

Under human rights law, the individual killed, or rather his or her heirs, have the right to have his/her violent death investigated. The right to life entails a procedural obligation to investigate suspicious deaths, ${ }^{83}$ regardless of whether the killing was conducted by State agents, ${ }^{84}$ private actors, ${ }^{85}$ or unknown perpetrators ${ }^{86}$ It is of no importance whether or not the deprivation of life was lawful or not. ${ }^{87}$ It is the failure to investigate a suspicious death that amounts to a violation of the right to life. ${ }^{88}$

In the current scenario, the State has not fulfilled its obligation to investigate. The lawfulness of the killing in question depends on the individual killed: If an enemy combatant was lawfully targeted, the deprivation of life does not amount to a violation of the right to life. Consequently, neither under international humanitarian law nor under human rights law does an obligation to investigate the death of a combatant exist.

If, on the other hand, the killed individual was a civilian, the killing was (most likely) unlawful and (most likely) amounts to murder or homicide unless the civilian was taking a direct part in hostilities, or the civilian must be considered collateral damage. Thus, under human rights law the State must investigate the death of the individual in order to assess its lawfulness. If an investigation is not commenced at all, not commenced promptly or not conducted effectively, ${ }^{89}$ the State may have violated its obligation under human rights to investigate the death. This holds true for acts in occupied territory as well. ${ }^{90}$

\section{IV.3. Extraterritorial Targeted Killings in Armed Conflicts}

Scenario: A targeted killing on State A's territory was conducted by State B with an aerial unmanned weapons systems controlled from B's territory without any troops of $\mathrm{B}$ on the ground in $\mathrm{A}$.

Legal scholarship is of the opinion that such killings with drones will not amount to an exercise of jurisdiction. ${ }^{91}$ However, it was submitted that human rights law can be 'divided and tailored' ${ }^{92}$ and specific human rights can be applied when a State exercises effective control over territory or over an individual. The use of drones amounts to an exercise of effective control. Thus, human rights law applies and the killing may be regarded as a violation of this body of law, depending on the circumstances of the specific case.

83 ECtHR, Silih v Slovenia, Appl. no. 71463/01, 9 April 2009, para. 159.

84 ECtHR, McCann and others v United Kingdom, Appl. no. 18984/91, 27 September 1995.

85 ECtHR, Menson v United Kingdom, Appl. no. 47916/99, 6 May 2003: "However, the absence of any direct State responsibility for the death of Michael Menson does not exclude the applicability of Article 2."

86 ECtHR, Togcu v Turkey, Appl. no. 27601/95, 31 May 2005, paras. 106 et seq.

87 ECtHR, Ramsahai and others v Netherlands, Appl. no. 52391/99, 15 May 2007 paras. 342, 289.

88 Human Rights Committee, Amirov v Russia, Appl. no. 1447/2006, 22 April 2009, para. 11.4. Cf. also ECtHR, Silih v Slovenia, Appl. no. 71463/01, 9 April 2009, para. 159.

89 ECtHR, Ceyhan Demirel and others v Turkey, Appl. No. 34491/97, 13 January 2005, para. 111.

90 ECtHR, al-Skeini, supra note 41.

91 Cf. Milanovic, M., "Al-Skeini and Al-Jedda in Strasbourg", supra note 35, 130.

92 ECtHR, al-Skeini, supra note 41, para. 137. 


\section{IV.4. Trailing and Monitoring an Individual}

Scenario: An unmanned system singles out an individual, follows the individual and monitors its behaviour over a few days. This scenario may precede scenarios IV.1 and IV.3. The prohibition of inhuman treatment, the right to liberty and security and the right to respect for private life may be violated.

Under human rights law it is prohibited to treat someone inhumanly. The difference between torture and inhuman treatment lays in the degree of suffering caused..$^{93}$ Even mental mistreatment may amount to a violation. ${ }^{94}$ If the individual notices the unmanned system, or if evoking this threat is the sole purpose of its use, this may cause a great amount of mental suffering and thus amount to inhuman treatment. Any treatment that may "be 'degrading' is also forbidden, because it could be such as to arouse in the victims feelings of fear, anguish and inferiority capable of humiliating and debasing them." 95 A machine cruising over an individual or following him constantly will arouse fear. As with the sword of Damocles, the person must always fear an attack on his life; even if the unmanned system is not weaponised, because the individual may not be able to tell the difference. Thus, in the present scenario the prohibition of inhuman or degrading treatment may be violated. A justification is not possible, unless the act itself does not amount to 'torture' or 'inhuman and/or degrading treatment and/or punishment'. Under art. 1 CAT 'torture' does "not include pain or suffering arising only from, inherent in or incidental to lawful sanctions." Thus, if such a treatment is the consequence of a lawful sanction, the prohibition of torture is not applicable.

The right to liberty and security (art. 5 ECHR and art. 9 [1] ICCPR) protects an individual's physical liberty. ${ }^{96}$ Any confinement in a particular restricted space for a considerable length of time against the will of the individual amounts to a loss of liberty. ${ }^{97}$ Security is not a separate human right, but forms an integral part of liberty. ${ }^{98}$ Even if an individual is followed over the course of days, he will not be confined in a particular restricted space. The mere monitoring does not hinder an individual from moving around freely. Thus, the surveillance does not amount to a violation of the right to liberty and security.

However, it may amount to a violation of the right to respect for private life (art. $8 \mathrm{ECHR}$ and art. 17 ICCPR). For the vast amount of possibilities, it is not possible to list exhaustively the contents of 'private life' ${ }^{99}$ In order to keep up with technological and social developments, the human rights bodies approach the issue of private life from the vantage point of which interests are protected by the right to respect for private life. One aspect of private life is the freedom from secret surveillance, even if conducted in a public space. ${ }^{100}$ However, if the surveillance equipment does not record the data, it was suggested that this would not amount to a violation of the right to respect for private life. ${ }^{101}$ Thus, if "the data available to a

93 Harris, D. J., O’Boyle, M., Bates, E. P., Buckles, C. M., eds., supra note 57, 75; Kretzmer, D., "Torture, Prohibition of", in: Wolfrum, R., ed., supra note 16, paras. 8 et seq.

94 Ibid.

95 ECtHR, Kudla v Poland, Appl. no. 30210/96, 26 October 2000, para. 92.

96 ECtHR, Engel and others v Netherlands, Appl. no. 5100/71, 5101/71, 5102/71, 5354/72 and 5370/72, 8 June 1976, para. 57.

97 ECtHR, Storck v Germany, Appl. no. 61603/00, 16 June 2005, para. 74.

98 ECtHR, Giorgi Nikolaishvili v Georgia, Appl. No. 37048/04, 13 January 2009, para. 52.

99 Harris, D. J., O’Boyle, M., Bates, E. P., Buckles, C. M., eds., supra note 57, 368.

100 Ibid., 361, 365.

${ }^{101}$ European Commission of Human Rights, Herbecq and the Association 'Ligue des droits de l'homme'v Belgium, Appl. no. 32200/96 and 32201/96, 14 January 1998, para. 3; ECtHR, Amann v Switzerland, 
person looking at monitors is identical to that which he or she could have obtained by being on the spot in person" 102 , the right to respect for private life is not applicable. If, in contrast, an individual is monitored within his/her home, encompassing private and business premises, it is of no importance of whether or not the monitoring is recorded. His/her interest is to be separated from public life and from interference from the outside world. Within the closed space of home, any surveillance will regularly amount to a violation of the right to privacy. ${ }^{103}$

This is not convincing. It is submitted that even without recording the constant surveillance of a person over the course of days, the surveillance may still violate the right to respect for private life. Two reasons support such an assessment. First, the right in question also protects a:

"right to establish and develop relationships with other human beings and the outside world and it may include activities of a professional or business nature. There is, therefore, a zone of interaction of a person with others, even in a public context, which may fall within the scope of 'private life'." 104

Constant surveillance will gather information about an individual's relationships with other human beings. This may deter an individual from entering or maintaining such relationships. Second, the line of arguments of the ECtHR dismissing a violation pertains to different factual circumstances. The case involved surveillance by stationary equipment that monitored certain premises. The use of drones, however, is fundamentally different. While an individual enters the monitored premises and can leave them again at free will, the unmanned system follows the individual, who has no possibility to exit surveillance. Unmanned systems therefore enable the State to survey an individual much more tightly than with stationary equipment.

Such a violation may be justified if the surveillance is prescribed by law, necessary in a democratic society and in the interests of national security or public safety, for the prevention of disorder or crime, for the protection of health or morals or for the protection of the rights and freedoms of others. ${ }^{105}$ Thus it depends on the circumstances of a case. If the individual is suspected of being a threat to human life (if this scenario precedes scenarios IV.1 and IV.3), then a justification would be possible. In any other circumstance, a justification seems unlikely.

In addition, if the monitored individual is a combatant or a member of an organized armed group, this right may be derogated from.

\section{IV.5. Monitoring Demonstrations and Riots}

Scenario: A few hundred persons demonstrate against an on-going war (or as the protesters call it, "foreign occupation on our beloved motherland") in front of a military compound. Within the compound, troops forming part of the occupation/peace operation are stationed. The demonstration is monitored by several unmanned aerial systems that cruise in low and high altitudes over the demonstration.

Appl. no. 27798/95, 16 February 2000, para. 65; ECtHR, Rotaru v Romania, Appl. no. 28341/95, 4

May 2000, paras. 43 ff.; ECtHR, Peck v United Kingdom, Appl. no. 44647/98, 28 January 2003, para. 59.

102 European Commission of Human Rights, Herbecq, supra note 101, para. 3.

103 Cf. also Harris, D. J., O’Boyle, M., Bates, E. P., Buckles, C. M., eds., supra note 57, 361.

104 ECtHR, Amann v Switzerland, supra note 101, para. 65; ECtHR, Rotaru v Romania, supra note 101, para. 43; ECtHR, Peck v United Kingdom, supra note 101, para. 57.

105 Cf. art. 8 (2) ECHR 
Some of the drones are equipped with jamming technology that interrupts every line of communication within the area of demonstration and to/from that area. After a while, some protesters start throwing rocks at the compound and the soldiers guarding it. In this scenario, the right of respect for private life, freedom of expression and the right to peaceful assembly may be violated. No derogation has been declared.

The gathering against the war in this scenario is protected under the right to peacefully assemble. Art. $11 \mathrm{ECHR}$ and art. 21 et seq. ICCPR protect the right to peacefully assemble for political, religious, cultural, social or other purposes. ${ }^{106}$ The assembly remains peaceful, until some protesters begin to throw rocks at the compound. Because the right to peacefully assemble is one of the foundations of a democratic society, the right "should not be interpreted restrictively." 107 Only in cases where "organisers and participants have violent intentions which result in public disorder" is the assembly not peaceful in the meaning of art. $11 \mathrm{ECHR} .{ }^{108}$

Authorities are under the obligation to make sure that the enjoyment of the right is effective. ${ }^{109}$ A monitoring of the demonstration as such may not amount to interference. But a high number of surveillance equipment may create an atmosphere of intimidation, thus hindering individuals from assembling in the first place or from remaining within such an assembly. A "chilling effect on the individuals concerned and on the other participants in the rallies" may amount to interference with the applicants' right to freedom of assembly. ${ }^{110}$ The use of drones, as in this scenario, builds an atmosphere of intimidation and certainly has a chilling effect on the protesters. Just three or four drones flying in low altitude will at least unsettle the demonstrators, if not intimidate them. Thus, in the present scenario, surveillance with low-flying drones interferes with the right to peacefully assemble.

This interference may be justified if a measure is prescribed by law, necessary in a democratic society and in the interests of national security or public safety, for the prevention of disorder or crime, for the protection of health or morals or for the protection of the rights and freedoms of others. State authorities enjoy a margin of appreciation in this regard. ${ }^{111}$ However, the "number of exceptions to freedom of expression and assembly, contained in Articles 10 and 11, is exhaustive. The definitions of those exceptions are necessarily restrictive and must be interpreted narrowly." 112 The criterion 'prescribed by law' constitutes a problem only in exceptional circumstances. ${ }^{113}$

The second requirement, 'necessary in a democratic society':

"implies that the interference corresponds to a 'pressing social need' and, in particular, that it is proportionate to the legitimate aim pursued. The Contracting States have a certain margin of appreciation in assessing

${ }^{106}$ Harris, D. J., O’Boyle, M., Bates, E. P., Buckles, C. M., eds., supra note 57, 516.

${ }^{107}$ ECtHR, G. v Germany, Appl. no. 13079/87, 6 March 1989, para. 2.

${ }^{108}$ ECtHR, Ibid.

${ }^{109}$ Harris, D. J., O’Boyle, M., Bates, E. P., Buckles, C. M., eds., supra note 57, 342.

110 ECtHR, United Macedonian Organisation Ilinen and Ivanov v Bulgaria (No. 2), Appl. no. 37586/04, 18 October 2011, para. 127.

111 European Commission of Human Rights, Christians against Racism and Fascism v United Kingdom, Appl. no. 8440/78, 16 July 1980, 149 et seq.

112 ECtHR, Sidiropoulos and Others v Greece, Appl. no., 10 July 1998, paras. 38 et seq.; ECtHR, Stankov and the United Macedonian Organisation Ilinden v Bulgaria, Appl. no. 29221/95 and 29225/95, 2 October 2001, para. 84.

113 The ECtHR has identified two requirements for 'law' in Sunday Times v United Kingdom, Appl. no. 6538/74, 26 April 1979, para. 49: It must be adequately accessible and it must be formulated with sufficient precision to enable the citizen to regulate his conduct. The Court left open the qualification of a Security Council Resolution as 'law' in al-Jedda, supra not e70. 
whether such a need exists. (...) The Court is therefore empowered to give the final ruling on whether a 'restriction' is reconcilable with the rights protected by the Convention." 114

States may take into consideration the question:

"whether there has been a call for the use of violence, an uprising or any other form of rejection of democratic principles. Where there has been incitement to violence against an individual or a public official or a sector of the population, the State authorities enjoy a wider margin of appreciation when examining the need for an interference with freedom of expression." 115

Also, the freedom of expression (art. $10 \mathrm{ECHR}$ and art. 19 ICCPR) may be violated. This right is closely related to the right to peacefully assemble. ${ }^{116}$ The freedom of expression protects not only the substance of information and ideas, but also a wide range of forms of expression. ${ }^{117}$ Thus, an assembly to protest against a war is covered by the freedom of expression as well. ${ }^{118}$ Violations may be justified for the same reasons as violations of the right to peaceful assembly may be justified.

Because of the constant monitoring of the situation on the ground, the right to respect for private life may be violated. ${ }^{119}$ As seen in scenario IV.4, surveillance with drones may interfere with this right. It may be justified for the same reasons as the right to peaceful assembly. ${ }^{120}$

As stated, deprivations of life are not violating the right to life when the deaths result from the use of force which is no more than absolutely necessary in action lawfully taken for the purpose of quelling a riot or insurrection. The terms 'riot' and 'insurrection' are not defined in case law. In a case similar to the present scenario, it was held that "an assembly of 150 persons throwing missiles at a patrol of soldiers to the point that they risked serious injury must be considered, by any standard, to constitute riot." 121 The amount of force used to counter a riot must be 'absolutely necessary'. Criteria are the proportionality of the use of force to the aim pursued, the degree of force employed in response and the risk that the use of force would result in the deprivation of life. ${ }^{122}$ Thus, in a riot, the throwing of rocks cannot be answered by lethal force. Only in very exceptional circumstances, when the life of the soldiers is at stake, may lethal force be used. In conclusion, it depends on the acts stemming from the demonstrations whether or not a violation of the right to life is justified.

114 ECtHR, Stankov, supra note 112, para. 87.

${ }^{115}$ ECtHR, Ibid., para. 90.

${ }^{116}$ Harris, D. J., O’Boyle, M., Bates, E. P., Buckles, C. M., eds., supra note 57, 516.

117 Ibid. 444.

${ }^{118}$ In ECtHR case law, if one violation is found, the Court will not assess the violation of any other human right.

119 Cf. supra scenario IV.4.

${ }^{120}$ Art. 8 ECHR on one side and art. 10,11 ECHR on the other are closely related. The violation of one often amounts to a violation of the other. Cf. ECtHR, Segerstedt-Wiberg and others $v$ Sweden, Appl. no. 62332/00, 6 June 2006: 'Nevertheless, the Court considers that the storage of personal data related to political opinion, affiliations and activities that is deemed unjustified for the purposes of Article $8 \S 2$ ipso facto constitutes an unjustified interference with the rights protected by Articles 10 and 11.

${ }^{121}$ European Committee of Human Rights, Stewart v United Kingdom, Appl. no. 10044/82, 10 July 1984, para. 25. Cf. also ECtHR, Gülec v Turkey, Appl. no. 21593/93, 27 July 1998, para. 70.

122 European Committee of Human Rights, Stewart v United Kingdom, Ibid., para. 26. 


\section{IV.6. Guarding Military Compounds or Detainment Centres}

Scenario: A detention center of State A, which is situated on the territory of State B, is guarded by unmanned aerial and ground systems of State A. An alarm is triggered as soon as the systems detect movement. Thereafter, an unmanned weapons system targets and kills the individual trying to flee the premises. In this scenario, the right to life, the right to liberty and security and the right to respect for private life may be violated. ${ }^{123}$

Following the above argumentation, State A has jurisdiction. The right to liberty and security protects the physical liberty of a person. Any confinement in a particular restricted space for a considerable length of time against the will of the individual amounts to a loss of liberty. ${ }^{124}$ Justification may be provided if the detention has a basis in, and conforms with, applicable domestic law, and the application of the domestic law is in conformity with the ECHR, especially art. 5 (1) (a)-(f) ECHR. ${ }^{125}$ If, as in the present scenario, the unmanned system monitors a prison where inmates are held, there is no violation of the right to liberty and security.

If the unmanned system targets and injures/kills an escapee, this will in most cases amount to a violation of the right to life or the prohibition of inhuman treatment. ${ }^{126}$ It then depends on the circumstances of each case whether or not the killing is lawful. If the escapee has a known history of violent crimes, his death may be justified. In other circumstances, the justification of a killing seems unlikely. Again, if death is the consequence of a lawful sanction, the prohibition of inhuman treatment does not apply.

Any violation of the right to respect for private life is justified for the guarding of prisons if prescribed by domestic law, necessary in a democratic society and in the interests of national security and public safety, for the prevention of disorder or crime, for the protection of health or morals or for the protection of the rights and freedoms of others. Likewise, the guarding of military compounds is also possible under the same legal reasoning. ${ }^{127}$

\section{Conclusion}

The use of unmanned systems, whether or not they are weaponised, raises questions of human rights law. Of utmost importance is the overall question of applicability and extraterritorial application. Due to technical differences between UMS and other military technology, human rights law applies to greater extent extraterritorially to the former than to the latter. It is submitted that the use of UAVs and similar UMS amounts to 'effective control' and 'jurisdiction' if a State exercises 'jurisdiction in waiting', meaning an extraterritorial situation in which a State may exercise all or some of the public powers normally to be exercised by that Government within an instant - which regularly entails the violation of a human right - while the exercise of public powers depends only on the will of the State and not on any other factor or behaviour, especially not on the individual concerned. The 'jurisdiction in waiting'

123 Within the de-militarized-zone between the Republic of Korea and the Democratic People's Republic of Korea such devices are already being used.

124 ECtHR, Storck, supra note 97, para. 74.

125 Harris, D. J., O'Boyle, M., Bates, E. P., Buckles, C. M., eds., supra note 57, 133.

126 Cf. supra scenario IV.1.

127 For this scenario cf. also. Kleffner, J., "Operational Detention and the Treatment of Detaineees", in Gill, T.,vand Fleck, D., eds., The Handbook of the International Law of Military Operations, Oxford University Press, Oxford, 2010, para. 25.01 et seq. 
18 GroJIL 1(1) (2013), 1-18

must be exercised over a considerable length of time that distinguishes the situation from a mere momentary presence of 'public power' or 'effective control'. Consequently, while using drones or other unmanned military systems, a State must comply with its human rights law obligations.

www.grojil.org 